Formatif: Jurnal Ilmiah Pendidikan MIPA

Vol. 9, No. 4, December 2019, pp. 267-280

p-ISSN: 2088-351X

e-ISSN: 2502-5457

DOI: http://dx.doi.org/10.30998/formatif.v9i4.2929

\title{
Flipped Classroom Learning Inovation as an Attempt to Strengthen Competence and Competitiveness of Students in the 4.0 Industrial Revolution Era
}

\author{
Inovasi Pembelajaran Flipped Classroom dalam Upaya Penguatan Kompetensi dan \\ Daya Saing Siswa Era Revolusi Industri 4.0
}

\author{
Halimatus Syakdiyah $(*)$ \\ Universitas Negeri Jakarta \\ Basuki Wibawa \\ Universitas Negeri Jakarta \\ Zulfati Syahrial \\ Universitas Negeri Jakarta
}

Received: October 23, 2018

Revised: December 02, 2019

Accepted: December 02, 2019

\begin{abstract}
Abstract: Industrial era 4.0, is an era of challenges and hopes for the world of education. In this disruptive era education must be able to improve and innovate in order to survive and continue to face the challenges of the times. The world of education has great hopes in the era of digitalization in an effort to facilitate the achievement of educational goals. This article wants to provide an overview of flipped classroom learning strategies in the 4.0 era with all the challenges. Based on the results of research that has been carried out proven flipped classroom strategy can effectively improve student chemistry learning outcomes. The research was carried out through a quantitative approach using an experimental method with $2 \times 2$ Treatment by Level design on chemistry subjects on Thermochemistry subject matter and rate of reaction. Thermochemistry and rate of reaction are the subjects with the lowest achievement in the 2016 National Examination (UN) results, which is $27 \%$ in Thermochemistry and $31 \%$ in the rate of reaction. Therefore, it is necessary to innovate learning strategies that are expected to be appropriate and can improve student learning outcomes in this 4.0 era. Then how should flipped classroom learning strategies be packaged in this disruptive era?
\end{abstract}

Keywords: Disruptive Era, 4.0 Industrial Era, Flipped Classroom

(*) Corresponding Author:

syakdiyah.70@gmail.com, +62 81315602276

How to Cite: Syakdiyah, H., Wibawa, B., \& Syahrial, Z. (2019). Flipped classroom learning inovation as an attempt to strengthen competence and competitiveness of students in the 4.0 industrial revolution era. Formatif: Jurnal Ilmiah Pendidikan MIPA, 9 (4): 267-280. http://dx.doi.org/10.30998/formatif.v9i4.2929

\section{PENDAHULUAN}

Berdasarkan hasil evaluasi tentang kesiapan negara menghadapi revolusi industri 4.0, Indonesia diperkirakan sebagai negara dengan potensi tinggi (Muhammad Nasir, 29 Januari 2018). Meskipun masih di bawah Singapura, di tingkat Asia Tenggara posisi Indonesia sangat diperhitungkan. Era revolusi industri 4.0 yang menekankan pada pola digital economy, artificial intelligence, big data, robotic, dan lain sebagainya atau dikenal 
Formatif: Jurnal Ilmiah Pendidikan MIPA

Vol. 9, No. 4, December 2019, pp. 267-280

p-ISSN: 2088-351X

e-ISSN: $2502-5457$

DOI: http://dx.doi.org/10.30998/formatif.v9i4.2929

dengan disruptive innovation. Menghadapi tantangan tersebut sistem pembelajaran di tingkat menengah pun dituntut berubah, karena saat ini kita menghadapi siswa milenial atau native digital. Di era revolusi industri 4.0 ini, kompetensi guru pun dituntut lebih, setidaknya ada lima kompetensi yang harus dimiliki 1) Educational competence, kompetensi yang berbasis Internet of Thing sebagai basic skill; 2) Competence research, kompetensi dalam menumbuhkan ilmu dan penelitian; 3) Competence for technological commercialization, memiliki kompetensi yang dapat membawa siswa pada situasi dan persaingan bisnis masa depan; 4) Competence in globalization, dunia tanpa sekat, tidak gagap terhadap berbagai budaya, kompetensi hybrid, yaitu global competence dan keunggulan memecahkan national problem; 5) Competence in future strategies, di mana dunia mudah berubah dan berjalan cepat, sehingga punya kompetensi memprediksi dengan tepat apa yang akan terjadi di masa depan dan strateginya, dengan cara pembentukan Musyawarah Guru Mata Pelajaran (MGMP), pengembangan penelitian, joint lab antar-sekolah, dan lain sebagainya.

Kompetensi siswa yang mampu menghadapi era industri 4.0 harus dimulai dari orientasi kurikulum dengan membangun pembelajaran daring atau blended learning. Sedangkan pada bidang pengembangan inovasi pembelajaran berbasis teknologi diperlukan pengelolaan riset/penelitian yang dilakukan oleh guru secara berkesinambungan, pengembangan pembelajaran yang bersinergi dengan dunia industri melalui pengembangan dan pengelolaan pembelajaran berbasis ICT, entrepreneurship dan lain sebagainya. Pemilihan strategi pembelajaran merupakan salah satu langkah yang dapat dilakukan untuk meningkatkan kualitas pembelajaran untuk mencapai tujuan pembelajaran. Pemilihan strategi pembelajaran diharapkan dapat meningkatkan kognitif, psikomotor sekaligus afektif siswa secara terpadu, sehingga sekolah dapat menghasilkan lulusan yang memiliki kemampuan kognitif yang mumpuni, yang mampu bersaing di dunia global, sekaligus memiliki keterampilan hidup yang sesuai dengan era industri 4.0 yang serba digital saat ini. Di era disruptive ini melalui sekolah pula siswa dibekali dengan nilai afektif yang mampu membawa siswa memiliki perilaku yang kuat, kokoh, beriman, serta memiliki motivasi tinggi untuk membangun diri, lingkungan, bangsa. dan negaranya.

Berbagai penelitian tentang strategi pembelajaran telah banyak dilakukan untuk mempermudah proses pembelajaran dalam mencapai tujuannya, mulai dari pendidikan tingkat dasar hingga perguruan tinggi. Dari hasil penelitian di berbagai negara, muncullah berbagai strategi pembelajaran dalam dunia pendidikan, antara lain strategi pembelajaran project based learning, problem based learning, discovery learning, problem posing, flipped classroom, pembelajaran langsung (ekspositori), dan lain-lain. Beberapa penelitian membuktikan bahwa strategi pembelajaran yang sesuai dengan tujuan pembelajaran dan karakteristik siswa, dapat meningkatkan hasil belajar. Sebagai contoh penelitian tentang penerapan strategi pembelajaran problem based learning berhasil meningkatkan pengetahuan konseptual, kemampuan berpikir kritis, kemampuan belajar tingkat tinggi yang pada akhirnya meningkatkan hasil belajar (Elaine, 2016; Sofie \& Loyen, 2014; Husnidar, 2014). Strategi pembelajaran flipped classroom, atau yang dikenal "kelas terbalik", merupakan strategi pembelajaran yang relatif baru di antara strategi pembelajaran yang lain. Dalam strategi pembelajaran flipped classroom, materi pelajaran disampaikan kepada siswa di rumah melalui media elektronik. Selanjutnya, menggunakan waktu di kelas untuk aktivitas praktik langsung. Pembelajaran ini merupakan pembelajaran yang berfokus kepada siswa. Untuk itu, sangat bergantung kepada kemampuan belajar mandiri siswa dengan memasukkan teknologi ke dalam proses pembelajaran mandirinya. Beberapa penelitian sebelumnya menyimpulkan bahwa 
Formatif: Jurnal Ilmiah Pendidikan MIPA

Vol. 9, No. 4, December 2019, pp. 267-280

p-ISSN: 2088-351X

e-ISSN: $2502-5457$

DOI: http://dx.doi.org/10.30998/formatif.v9i4.2929

memasukkan teknologi ke dalam pembelajaran dapat meningkatkan hasil belajar siswa (Shu, 2015; Lo, 2017; Garza, 2017).

Flipped classroom merupakan salah satu strategi pembelajaran yang menggunakan IT dalam pembelajaran. Strategi pembelajaran ini melibatkan siswa secara aktif untuk belajar secara mandiri melalui media video sebelum masuk kelas. Kelas digunakan hanya untuk berinteraksi secara aktif dalam menyelesaikan masalah yang sulit (To 2014; Henson, 2015; Bergman, Rotellar, \& Cain, 2016; Mok, 2017). Di samping itu, flipped classroom juga terbukti efektif untuk kelas yang besar, mampu menimbulkan persepsi positif siswa terhadap proses pembelajaran, serta dapat meningkatkan hasil belajar (Stone, 2012; McLaughlin, 2014; Persky \& Laughlin 2017; Yestrebskya, 2014; Beatty \& Brian, 2016).

Berdasarkan keberhasilan penerapan strategi flipped classroom tersebut di atas, yang sebagian besar dilakukan di perguruan tinggi, peneliti sebagai guru, merasa terpanggil untuk meneliti lebih jauh tentang efektivitas strategi flipped classroom pada tingkat sekolah menengah. Di samping itu, situasi saat ini, generasi milenial atau yang dikenal sebagai generasi native digital, suatu generasi yang terlahir dalam lingkungan digital (Prensky, 2001), memiliki ketergantungan yang sangat tinggi terhadap teknologi (gadget). Oleh karenanya, diperlukan pembelajaran yang terintegrasi dengan lingkungan (teknologi) dan kebiasaan mereka. Dibutuhkan desain pembelajaran yang serba praktis dan mudah dengan mengintegrasikan teknologi ke dalamnya. Strategi pembelajaran yang dapat digunakan pada era milenial ini adalah strategi pembelajaran flipped classroom, dengan mengintegrasikan teknologi ke dalam pembelajaran melalui video pembelajaran yang dirancang sedemikian rupa, sehingga dapat mengefektifkan waktu belajar siswa di dalam kelas.

Dalam kelas tradisional, guru menyampaikan pembelajaran di kelas kemudian memberikan pekerjaan rumah kepada siswa untuk dikerjakan setelah kelas selesai. $A$ flipped classroom is a model of learning that readjusts and reschedules time spent both in and out of the classroom that enhances the shifting of ownership of learning to the student undertaking the studies from the teachers and educators. Flipped classroom adalah model pembelajaran yang mengatur ulang dan menjadwal ulang waktu yang digunakan di luar kelas maupun di dalam kelas, dengan meningkatkan waktu belajar mandiri siswa dibandingkan dengan belajar dari guru atau pendidik (Kashada, 2017). The flipped classroom is a pedagogical approach in which basic concepts are provided students for pre-class learning so that class time can apply and build upon those basic concepts. Flipped classroom adalah pendekatan pedagogis di mana konsep dasar diberikan kepada siswa untuk pembelajaran pra-kelas, sehingga waktu kelas dapat diterapkan dan dibangun di atas dasar itu konsep yang telah dipelajarinya (Persky, 2017). Seperti yang dikatakan Bergman dalam buku Carbough \& Doubet yang berjudul The Differentiated, seorang guru yang menggunakan flipped classroom memegang kontrol penuh kepada siswa mereka serta menganggap siswa bertanggung jawab atas pembelajarannya sendiri. Dalam hal ini, siswa diberikan ruang untuk belajar secara mandiri, sedangkan guru berfungsi sebagai kontrol terhadap kegiatan yang dilakukan oleh siswa (Carbaugh, 2014 ). Bergmann \& Sams menciptakan bentuk kelas terbalik untuk mendeskripsikan suatu model pembelajaran yang menggabungkan pembelajaran langsung dengan pengalaman belajar konstruktivis. Model ini memberi kesempatan untuk membawa teknologi secara lebih alami ke dalam kelas dan mengeksplorasi lebih banyak cara kreatif untuk melibatkan siswa dalam belajar (Smaldino, 2012).

Menurut hasil penelitian yang dilakukan oleh Baytiyeh (2016) disimpulkan bahwa pembelajaran flipped classroom dapat mengoptimalkan waktu di kelas, meningkatkan kemampuan berpikir tingkat tinggi, mempromosikan aktivitas kerja 
Formatif: Jurnal Ilmiah Pendidikan MIPA

Vol. 9, No. 4, December 2019, pp. 267-280

p-ISSN: 2088-351X

e-ISSN: 2502-5457

DOI: http://dx.doi.org/10.30998/formatif.v9i4.2929

kelompok, meningkatkan keterampilan pemecahan masalah, dan memfasilitasi interaksi antara guru-siswa serta interaksi siswa-siswa. Dalam studi ini juga ditemukan bahwa strategi flipped classroom dapat memperkaya pengalaman belajar siswa dan dapat membantu mereka mengembangkan soft skill yang mereka butuhkan untuk sukses dalam profesi apa pun. Penelitian tentang penggunaan strategi flipped classroom pada mata kuliah Kimia dilakukan oleh Yetrebsky (2014) yang menunjukkan bahwa penggunaan strategi pembelajaran flipped classroom dapat meningkatkan persentase nilai akhir yang tinggi (A dan B) pada mahasiswa dalam mata kuliah Kimia, dibandingkan dengan mahasiswa yang belajar dengan menggunakan strategi pembelajaran tradisional.

Skema berikut menunjukkan perbedaan kelas tradisional dengan flipped classroom.

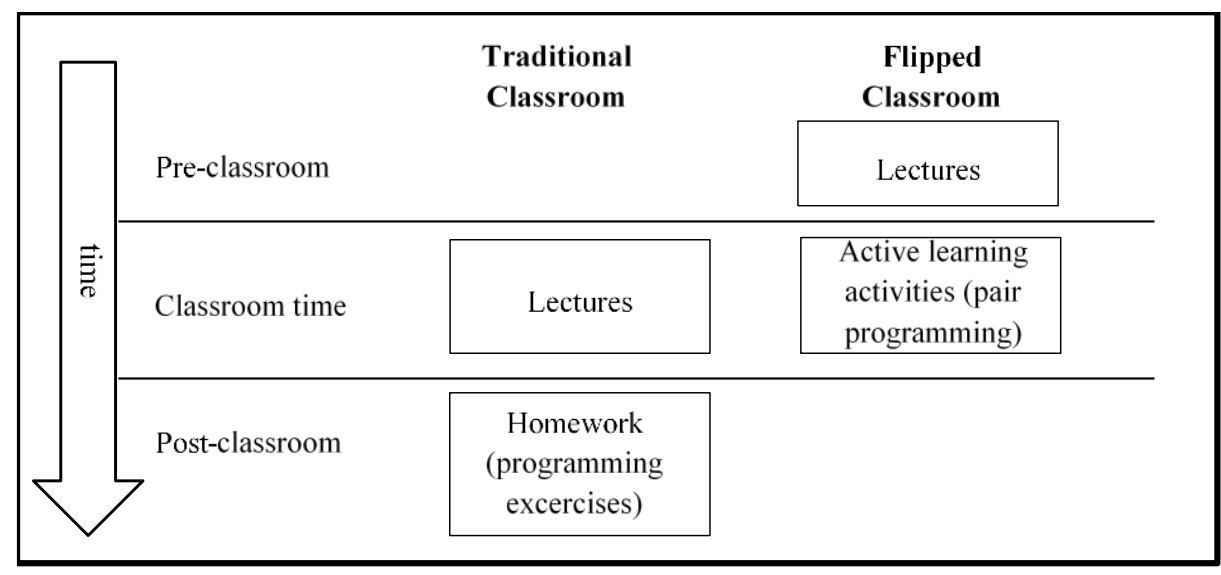

Gambar 1. Skema Perbedaan Kelas Tradisional dengan Flipped Classroom

Pada gambar 1. tampak perbedaan kegiatan kelas tradisional dan kelas terbalik. Pada kelas tradisional guru menjelaskan materi pelajaran di kelas, kemudian guru memberikan tugas (pekerjaan rumah) kepada siswa. Sedangkan pada flipped Classroom guru memberikan siswa materi untuk dipelajari secara mandiri oleh siswa sebelum masuk kelas, kemudian guru mendampingi siswa dalam menyelesaikan masalah/soal. Pada proses pembelajaran flipped classroom siswa secara aktif memecahkan masalahnya berdasarkan kemampuan yang diperoleh saat belajar mandiri. Pada pembelajaran tradisional pembelajaran di kelas menjadi dominasi guru, sedangkan pada flipped classroom pembelajaran di kelas didominasi oleh siswa yang didampingi oleh guru. Selain itu pada flipped classroom siswa dapat membangun pengetahuannya secara mandiri sebelum mereka melakukan praktik menyelesaikan masalahnya di kelas. Dalam strategi ini, guru menyediakan materi secara online, dan menugaskan siswa untuk membaca, mengamati, menguraikan, meringkas, memahami, dan mempresentasikannya pada saat di kelas.

Menurut hasil riset didasarkan dari Teori Bloom, yang terdiri dari enam tingkatan Taksonomi Bloom, dapat dilihat dalam pembelajaran flipped classroom. 
Formatif: Jurnal Ilmiah Pendidikan MIPA

Vol. 9, No. 4, December 2019, pp. 267-280

p-ISSN: 2088-351X

e-ISSN: 2502-5457

DOI: http://dx.doi.org/10.30998/formatif.v9i4.2929

Tabel 1. Tingkatan Taksonomi Bloom dalam Kelas Tradisional dan Flipped Classroom

\begin{tabular}{|c|c|c|}
\hline Level belajar & Kelas Flipped & Kelas Tradisional \\
\hline Mengingat & $\begin{array}{l}\text { Pembelajaran yang telah direkam } \\
\text { sebelumnya, bahan bacaan, dan melihat } \\
\text { video pembelajaran secara independen }\end{array}$ & Kelas tatap muka \\
\hline Memahami & $\begin{array}{l}\text { Refleksi, diskusi berpasangan, dan } \\
\text { kolaborasi }\end{array}$ & Tanya jawab \\
\hline Menganalisa & Aktivitas kelas seperti diskusi kelompok & Pekerjaan rumah \\
\hline $\begin{array}{l}\text { Mengaplikasi, } \\
\text { mengevaluasi, } \\
\text { menciptakan }\end{array}$ & $\begin{array}{l}\text { Proyek siswa, evaluasi berpasangan, } \\
\text { dan evaluasi guru }\end{array}$ & $\begin{array}{l}\text { Pekerjaan rumah atau } \\
\text { tidak sama sekali }\end{array}$ \\
\hline
\end{tabular}

Dari tabel 1. tampak perbedaan level belajar berdasarkan Taksonomi Bloom, Pada tahapan pertama yakni mengingat, untuk kelas tradisional adalah dilakukan di kelas secara tatap muka antara siswa dan guru, sedangkan pada flipped classroom siswa melakukannya sendiri melalui rekaman, bahan bacaan, dan melihat video pembelajaran secara independen di luar kelas. Pada level pemahaman dilakukan melalui tanya jawab di kelas, sedangkan dalam flipped classroom dilakukan melalui proses refleksi, diskusi kelompok. Pada level kegiatan analisis pada kelas tradisional diberikan dalam bentuk pekerjaan rumah (PR), sedangkan pada flipped classroom dilakukan dalam bentuk aktivitas kelas dengan diskusi dan tanya jawab. Kemudian pada level aplikasi, evaluasi dan mencipta pada kelas tradisional bisa dilakukan di rumah (PR) atau tidak dilakukan, sedangkan pada flipped classroom dilakukan oleh siswa dalam bentuk presentasi atau hasil karya serta evaluasi pembelajaran.

Apabila terjadi masalah dengan jaringan internet, flipped classroom tetap bisa dilakukan dengan memodifikasi pembelajaran melalui video, memindahkan melalui flashdisk,atau melalui komunitas dalam sosial media tertentu sehingga siswa dapat melakukan pembelajaran di rumah. Kondisi ini bisa juga diatasi dengan penggunaan media sekolah secara bersama-sama di luar jadwal belajar.

Menurut Mazur dalam Cockrum, terdapat tujuh langkah dalam pembelajaran flipped, yaitu: 1) Siswa melakukan aktivitas pra-kelas, melalui video, atau media interaktif; 2) Di kelas, guru bertanya tentang aktivitas pra-kelas siswa dengan pertanyaan tingkat tinggi yang tidak mudah dijawab; 3) Siswa menggunakan pengetahuan dasar mereka untuk menentukan jawabannya; 4) Guru me-review jawaban siswa melalui sistem respons, melalui metode cepat; 5) Mencari jawaban yang berbeda untuk didiskusikan dan membahas alasan pemilihan jawaban, proses ini adalah penjelajahan pengetahuan siswa; 6) Siswa ditanya kembali untuk komit dengan jawabannya; 7) Guru me-review jawaban yang benar, memberikan penjelasan konsep, dan menjelaskan kebutuhan pembelajaran lainnya.

Menurut Cockrum dengan pembelajaran flipped classroom, guru dapat memberikan perhatian kepada siswa yang kesulitan dan penilaian untuk kebutuhan mereka. Guru mempunyai fleksibilitas untuk memberikan alternatif penilaian pada tingkat individu, serta memiliki waktu berdiskusi lebih dengan siswa untuk membantu kesulitannya. Jika terdapat siswa yang ketinggalan dalam pembelajaran, guru memodifikasi tugas atau mengulang kembali pelajaran yang tidak dimengerti. Kegelisahan dari siswa berkemampuan tinggi juga tetap ingin berhasil dalam pembelajaran flipped classroom . Artinya, pada pembelajaran flipped classroom tidak hanya siswa berkemampuan rendah yang beruntung, tetapi juga menguntungkan bagi siswa berkemampuan tinggi. 
Formatif: Jurnal Ilmiah Pendidikan MIPA

Vol. 9, No. 4, December 2019, pp. 267-280

p-ISSN: 2088-351X

e-ISSN: 2502-5457

DOI: http://dx.doi.org/10.30998/formatif.v9i4.2929

Basal (2015), menyimpulkan bahwa dalam pembelajaran terbalik diperoleh beberapa keuntungan, antara lain kesempatan belajar yang berpusat pada siswa, hubungan yang terus-menerus antara guru dan siswa, peningkatan motivasi siswa, variasi metode ceramah yang dapat disesuaikan dengan gaya belajar, kesempatan belajar yang disesuaikan dengan kemampuan belajar masing-masing siswa. Basal juga menyatakan kelemahan dari flipped classroom sangat bergantung kepada kemampuan guru dalam menyiapkan atau mencari video yang dapat digunakan sebagai media pembelajaran online. Namun hal ini dapat disiasati dengan memilih berbagai media online yang marak saat ini, selanjutnya siswa dapat mengakses dari tempat masing-masing. Pada pendidikan tinggi, dalam sebuah penelitian, diperoleh hasil bahwa flipped classroom memberikan dampak peningkatan peran dan komunikasi mahasiswa dan dosen, selain itu dengan memasukkan ICT ke dalam pembelajaran, dapat meningkatkan minat mahasiswa dan kemampuan akademik (Flores, 2016). Hasil penelitian terakhir dari penelitian penerapan flipped classroom yang berjudul "Current Problems With the Prerequisites for Flipped Classroom Teaching - a Case Study in a University in Northwest China" disimpulkan bahwa kegagalan dalam penerapan flipped classroom dapat disebabkan antara lain rendahnya pemantauan terhadap kegiatan e-learning pada siswa, kurangnya pengetahuan yang memadai tentang ilmu komputer dan teknologi komunikasi yang dimiliki oleh guru (Li, 2018).

Dari berbagai uraian di atas dapat disimpulkan, pembelajaran flipped classroom adalah strategi pembelajaran yang direncanakan oleh guru, melibatkan aktivitas siswa secara aktif di kelas sebagai praktik yang didahului oleh aktivitas di luar kelas sebagai proses belajar mandiri dengan menggunakan fasilitas teknologi dengan tujuan meningkatkan keterlibatan siswa dalam belajar. Dalam rangka mengeksperimenkan strategi flipped classroom di kelas eksperimen, akan dibandingkan dengan pembelajaran ekspositori di kelas kontrol.

Strategi pembelajaran ekspositori adalah strategi pembelajaran yang menekankan kepada proses penyampaian materi secara verbal dari seorang guru kepada sekelompok siswa dengan maksud agar siswa dapat menguasai materi pelajaran secara optimal (Kemdikbud, 2015). Dikatakan dalam sebuah jurnal, pendekatan ekspositori adalah pendekatan paling tua yang digunakan untuk mengajar mata pelajaran sains dan seni (Agbulu, 2008). Pendekatan ini melibatkan presentasi ide, konsep, prinsip, generalisasi, dan fakta. Tujuannya adalah menyampaikan atau menanamkan informasi kepada siswa. Guru banyak melakukan kegiatan berbicara, sedangkan siswa pasif atau sedikit terlibat. Guru harus dapat mengeksplorasi pengetahuannya dan menyampaikan informasi tersebut secara efektif kepada siswa.

Terdapat beberapa karakteristik dalam strategi pembelajaran ekspositori antara lain: 1) Penyampaian materi secara verbal; 2) Materi yang disampaikan merupakan materi yang sudah jadi, yaitu materi lengkap yang telah disiapkan oleh guru untuk disampaikan kepada siswa; 3) Tujuan utama pembelajaran adalah penguasaan materi pelajaran itu sendiri.

\section{METODE}

Penelitian tentang strategi pembelajaran flipped calssroom yang telah dilakukan menggunakan pendekatan kuantitatif dengan metode kuasi eksperimen, satu kelas digunakan sebagai kelas eksperimen dengan menggunakan strategi pembelajaran flipped classroom dan satu kelas kontrol dengan menggunakan strategi pembelajaran ekspositori. Penelitian ini bertujuan mengetahui pengaruh strategi pembelajaran flipped classroom 
terhadap hasil belajar. Penelitian dilakukan di SMAN 1 Setu pada siswa kelas XI program MIPA tahun pelajaran 2017/2018. Populasi target dalam penelitian ini adalah seluruh siswa kelas XI program MIPA SMAN se-Kabupaten Bekasi, sedangkan populasi terjangkaunya adalah siswa kelas XI program MIPA SMAN 1 Setu Kabupaten Bekasi angkatan 2017/2018 yang terdiri dari lima kelas. Sedangkan sampel penelitian di-random dua kelas untuk penelitian: satu kelas eksperimen dan satu kelas kontrol.

Tahapan penelitian meliputi penelitian pendahuluan, yaitu penyebaran kuesioner kepada siswa dan guru untuk menemukan masalah di lapangan. Tahap awal penelitian (persiapan) yaitu pembuatan video pembelajaran untuk strategi flipped classroom, membuat rencana pelaksanaan pembelajaran (RPP), pembuatan instrumen penelitian, serta melakukan uji validitas dan reliabilitas terhadap instrumen tersebut. Proses pembuatan instrumen melalui tahap berikut, (1) telaah bahan ajar atau teori yang relevan (2) membuat definisi konseptual dan definisi operasional (3) pengembangan indikator (4) membuat kisi-kisi instrumen (5) penulisan butir instrumen (6) melakukan validitas oleh pakar (7) revisi instrumen (8) validasi instrumen dengan uji coba instrumen pada populasi di luar sampel penelitian (9) analisis dan seleksi instrumen yang valid (10) menghitung reliabilitas dari instrumen yang valid.

Tahap pelaksanaan yaitu melaksanakan pembelajaran flipped classroom pada kelas eksperimen, dan pembelajaran ekspositori pada kelas kontrol sebanyak 16 kali pertemuan. Tahap akhir penelitian dengan memberikan tes hasil belajar Kimia pada semua siswa, baik kelas eksperimen maupun kelas kontrol. Kemudian dilanjutkan dengan analisis data baik secara deskriptif maupun inferensial.

Pada penelitian ini juga dilakukan kontrol terhadap validitas internal maupun eksternal. Validitas internal ialah seberapa jauh hubungan antara perlakuan (variabel sebab) dengan kriterian (variabel akibat) benar-benar merupakan hubungan sebab-akibat yang bisa dipastikan. Dengan kata lain, perubahan subjek mengenai hal-hal yang ingin dipengaruhi (variabel kriterian) betul-betul akibat dari perlakuan yang diberikan, bukan karena faktor lain. Faktor-faktor tersebut menurut Ary antara lain sejarah (history), pematangan diri (maturation), pemberian pre-tes (testing effect), seleksi (selection bias), regresi statistik (statistical regression), hilang dalam penelitian (experimental mortality), efek subjek (subject effect), instrumen (instrumentation), efek eksperimental (experimenter effect), penyebaran (diffusion), perbedaan kematangan (selectionmaturation ineraction). Validitas eksternal berkaitan dengan nilai generalisasi dari suatu eksperimen. Maksudnya, seberapa jauh suatu hasil eksperimen dapat digeneralisasikan terhadap populasi lain. Ancaman untuk validitas eksternal menurut Ary, Jacobs, Sorensen, \& Razavieh antara lain seleksi-interaksi perlakuan (selection-treatment interaction), pengaturan-interaksi perlakuan (setting-treatment interaction), pretestinteraksi perlakuan (pretest-treatment interaction), dampak subjek (subject effects), dampak perlakuan (experimental effects). Semua faktor validitas internal maupun eksternal sebisa mungkin dalam penelitian eksperimen ini dikendalikan.

Data hasil belajar siswa dikumpulkan melalui hasil tes belajar Kimia pada bab termokimia dan laju reaksi. Hasil belajar Kimia adalah skor total yang diperoleh siswa setelah mengikuti proses pembelajaran dan tes Kimia pada pokok bahasan laju reaksi dan kesetimbangan kimia. Ranah kognitif, yang meliputi pengetahuan $(\mathrm{C} 1)$, pemahaman $(\mathrm{C} 2)$, penerapan (C3), analisa (C4), dijaring melalui proses penilaian melalui tes yang dilakukan dalam bentuk soal pilihan ganda dengan skor 1 untuk yang menjawab benar dan skor 0 untuk yang menjawab salah. Instrumen sebelumnya sudah divalidasi oleh ahli materi dan ahli desain instruksional, selanjutnya dihitung validitas dan reliabilitasnya dengan diujicobakan kepada siswa kelas di atasnya (kelas XII) yang telah mengikuti materi termokimia dan laju reaksi. Uji validitas empirik menggunakan rumus point 
Formatif: Jurnal Ilmiah Pendidikan MIPA

Vol. 9, No. 4, December 2019, pp. 267-280

p-ISSN: 2088-351X

e-ISSN: $2502-5457$

DOI: http://dx.doi.org/10.30998/formatif.v9i4.2929

biserial, dengan taraf signifikansi $\alpha=0,05$. Setiap butir dikatakan valid jika mempunyai (r) yang signifikan pada taraf signifikansi yang dipilih. Hasil perhitungan validitas instrumen hasil belajar kimia dengan menggunakan rumus point biserial, dari 44 soal yang telah diujicobakan, terdapat lima butir soal yang tidak valid antara lain butir nomor $18,22,35,41$, dan 43, sehingga butir yang dinyatakan valid ada 39 butir. Karena keterbatasan waktu tes, dari 39 butir yang dinyatakan valid, hanya diambil 35 butir tes yang digunakan dalam penelitian. Di mana soal dengan indikator yang sama hanya diambil salah satu. Perhitungan reliabilitas instrumen menggunakan rumus KR 20, Hasil perhitungan reliabilitas dengan menggunakan rumus KR 20, menunjukkan nilai reabilitas dengan $r$ hitung $=0818$ dengan demikian instrumen tes dinyatakan reliabel. Data hasil belajar kimia sebelum dianalisis, terlebih dahulu dilakukan uji prasyarat yaitu uji normalitas dan uji homogenitas sebagai syarat dapat dilakukan analisis statistik. Dalam penelitian ini, uji normalitas dilakukan dengan Kolmogorof Smirnov dengan kriteria pengujian jika D0 $\leq$ D-tabel maka H0 diterima. Jika D0 $>$ D-tabel maka H0 ditolak. Dengan kesimpulan jika $\mathrm{D} \leq \mathrm{D}$-tabel sampel berasal dari populasi berdistribusi normal. D0> D-tabel : sampel berasal dari populasi berdistribusi tidak normal. Uji homogenitas dilakukan untuk mengetahui apakah variabel pada dua atau lebih kelompok data sampel berasal dari varian yang sama atau tidak. Uji homogenitas dengan menggunakan uji bartlett. Uji homogenitas dilakukan untuk menilai adakah perbedaan varian antara kedua kelompok atau lebih. Hasil uji nornalitas sampel dinyatakan terdistribusi normal., serta hasil uji homogenitas sampel dinyatakan berasal dari variansi yang sama. Data dinyatakan normal dan berasal dari varians yang sama, maka selanjutnya dilakukan analisis untuk menentukan adakah perbedaan yang signifikan antara dua strategi yang dieksperimenkan tersebut.

\section{HASIL DAN PEMBAHASAN}

\section{Hasil}

Data mengenai hasil belajar kimia dengan menggunakan metode flipped classroom didapat melalui tes yang berisi 35 butir soal dengan skor masing-masing 0 dan 1. Rentangan skor secara teoritis adalah 0 sampai 35, di mana 0 adalah skor terendah dan 35 adalah skor tertinggi. Rentangan skor hasil belajar secara empiris diperoleh dari perhitungan pada kelompok siswa yang belajar dengan strategi flipped classroom memiliki skor terendah 11 dan skor tertinggi 29, rata-rata skor 20,50, median 21, dan simpangan baku 4,404. Sedangkan data mengenai hasil belajar kimia dengan menggunakan metode ekspositori didapat skor terendah 5 dan skor tertinggi 25 , rata-rata 14,13, median 14,00 dan simpangan baku 4,884. Dari hasil belajar dua kelas tersebut di atas dapat dikatakan bahwa hasil belajar kelas flipped classroom lebih tinggi dibandingkan dengan hasil belajar kelas ekspositori. Melalui uji simple effect antara siswa yang dibelajarkan dengan strategi pembelajaran flipped classroom dan siswa yang dibelajarkan dengan ekspositori diperoleh hasil Fhitung $=5,41$. dan Ftabel $=1,67$ karena Fhitung > Ftabel maka menolak H0 dan menerima H1 (H0: $\mu \mathrm{A} 1=\mu \mathrm{A} 2$ dan $\mathrm{H} 1: \mu \mathrm{A} 1>$ $\mu \mathrm{A} 3)$. Jadi hasil belajar kimia siswa yang dibelajarkan dengan strategi pembelajaran flipped classroom lebih tinggi jika dibandingkan dengan hasil belajar siswa yang dibelajarkan dengan strategi pembelajaran ekspositori.

Uji hipotesis dalam penelitian ini menggunakan anova dua jalur, dengan hasil sebagai berikut: 
Formatif: Jurnal Ilmiah Pendidikan MIPA

Vol. 9, No. 4, December 2019, pp. 267-280

p-ISSN: 2088-351X

e-ISSN: 2502-5457

DOI: http://dx.doi.org/10.30998/formatif.v9i4.2929

Tabel 2. Tests of Between-Subjects Effects

Dependent Variable: Learnig_outcomes

\begin{tabular}{|c|c|c|c|c|c|}
\hline Source & $\begin{array}{l}\text { Type III Sum } \\
\text { of Squares }\end{array}$ & $\mathrm{df}$ & Mean Square & $\mathrm{F}$ & Sig. \\
\hline Corrected Model & $621,729^{a}$ & 3 & 207,243 & 10,596 & 000 \\
\hline Intercept & 14386,687 & 1 & 14386,687 & 735,564 &, 000 \\
\hline Strategy & 487,688 & 1 & 487,688 & 24,935 &, 000 \\
\hline Self_directed_learning & 46,021 & 1 & 46,021 & 2,353 &, 132 \\
\hline Strategy * & 88,021 & 1 & 88,021 & 4,500 & 040 \\
\hline \multicolumn{6}{|l|}{ Self_directed_learning } \\
\hline Error & 860,583 & 44 & 19,559 & & \\
\hline Total & 15869,000 & 48 & & & \\
\hline Corrected Total & 1482,313 & 47 & & & \\
\hline
\end{tabular}

a. $\quad$ R Squared $=, 419$ (Adjusted R Squared $=, 380$ )

Tabel 3. Univariate Tests

Dependent Variable: Learning_outcomes

\begin{tabular}{|c|c|c|c|c|c|}
\hline & $\begin{array}{l}\text { Sum of } \\
\text { Squares }\end{array}$ & Df & Mean Square & $\mathrm{F}$ & Sig. \\
\hline Contrast & 487,688 & 1 & 487,688 & 24,935 & $\overline{, 000}$ \\
\hline Error & 860,583 & 44 & 19,559 & & \\
\hline
\end{tabular}

The $\mathrm{F}$ tests the effect of Strategy. This test is based on the linearly independent pairwise comparisons among the estimated marginal means.

Berdasarkan data analisis pada tabel 2 dan 3, dapat disimpulkan sebagai berikut:

1. Perbedaan hasil belajar kimia antara siswa yang dibelajarkan dengan strategi flipped classroom dan strategi pembelajaran ekspositori.

Berdasarkan hasil perhitungan diperoleh perbedaan hasil belajar siswa pada siswa yang belajar dengan strategi flipped classroom dengan siswa yang belajar dengan startegi ekspositori diperoleh $\mathrm{F}_{\text {hitung }}=24,935$ dan nilai $\mathrm{F}_{\text {tabel }} 3,18$. Karena nilai $\mathrm{F}_{\text {hitung }}$ $>\mathrm{F}$ tabel, maka $\mathrm{H}_{0}$ ditolak. Kemudian jika dilihat dari nilai Sig 0,000 artinya strategi pembelajaran berpengaruh secara signifikan terhadap hasil belajar kimia.

2. Terdapat pengaruh interaksi antara strategi pembelajaran dan kemandirian belajar terhadap hasil belajar kimia. Berdasarkan perhitungan anova dua jalur diperoleh $\mathrm{F}_{\text {hitung }}$ $=4.500$ dan $\mathrm{F}_{\text {tabel }}=3,18$. Karena nilai $\mathrm{F}_{\text {hitung }}>\mathrm{F}_{\text {tabel, }}$ maka menolak $\mathrm{H}_{0}$ dan menerima $\mathrm{H}_{1}$. Adanya interaksi juga dapat dilihat dalam bentuk grafik seperti gambar 2. 
Formatif: Jurnal Ilmiah Pendidikan MIPA

Vol. 9, No. 4, December 2019, pp. 267-280

p-ISSN: 2088-351X

e-ISSN: 2502-5457

DOI: http://dx.doi.org/10.30998/formatif.v9i4.2929

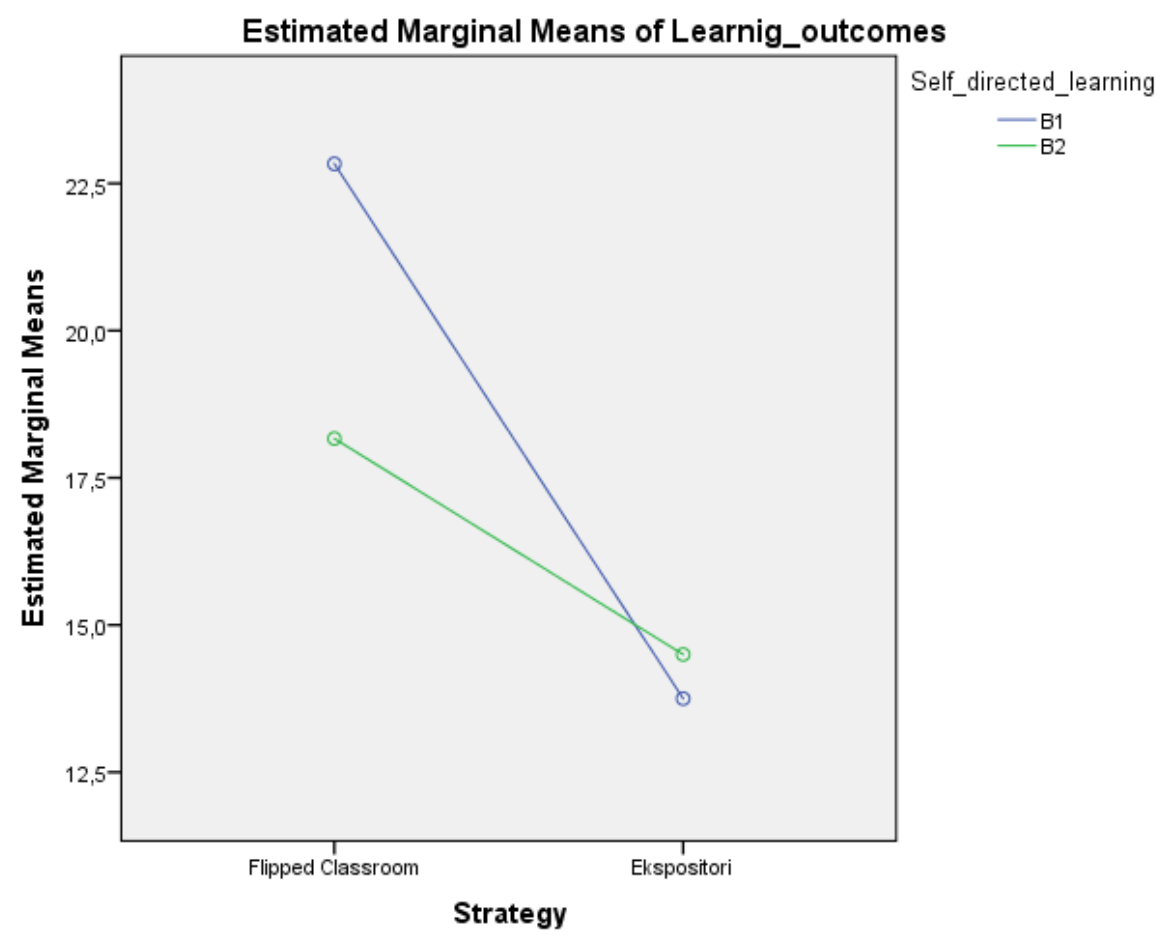

Gambar 2. Grafik pengaruh interaksi antara strategi pembelajaran dan kemandirian belajar

3. Terdapat perbedaan hasil belajar kimia siswa yang dibelajarkan dengan flipped classroom dan siswa yang dibelajarkan dengan strategi ekspositori untuk siswa yang memiliki kemandirian belajar tinggi.

\begin{tabular}{|c|c|c|c|c|c|c|c|c|c|c|}
\hline \multicolumn{11}{|c|}{ Independent Samples Test } \\
\hline & & \multicolumn{2}{|c|}{$\begin{array}{l}\text { Levene's } \\
\text { Test for } \\
\text { Equality of } \\
\text { Variances }\end{array}$} & \multicolumn{7}{|c|}{ t-test for Equality of Means } \\
\hline & & & & & & & Mean & $\begin{array}{l}\text { Std. } \\
\text { Error }\end{array}$ & $\begin{array}{r}95 \% \text { Cor } \\
\text { of th }\end{array}$ & $\begin{array}{l}\text { nce Interval } \\
\text { ference }\end{array}$ \\
\hline & & $\mathrm{F}$ & Sig. & $\mathrm{t}$ & df & $\begin{array}{l}\text { Sig. (2- } \\
\text { tailed) }\end{array}$ & $\begin{array}{l}\text { Differ } \\
\text { ence }\end{array}$ & $\begin{array}{c}\text { Differen } \\
\text { ce }\end{array}$ & & Upper \\
\hline \multirow[t]{2}{*}{$\begin{array}{l}\text { Learning } \\
\text { outcomes } \\
\text { chemistry }\end{array}$} & $\begin{array}{l}\text { Equal } \\
\text { variances } \\
\text { assumed }\end{array}$ &, 833 &, 371 & 4,667 & 22 &, 000 & 9,083 & 1,946 & 5,047 & 13,119 \\
\hline & $\begin{array}{l}\text { Equal } \\
\text { variances not } \\
\text { assumed }\end{array}$ & & & 4,667 & 19,560 &, 000 & 9,083 & 1,946 & 5,018 & 13,149 \\
\hline
\end{tabular}

Berdasarkan hasil independent sample test diperoleh nilai Sig (2 tailed) 0,000, dengan menggunakan nilai signifikansi $\alpha=0,05$ diperoleh nilai Sig $<0,05$ sehingga $\mathrm{H}_{0}$ ditolak. Artinya terdapat perbedaan hasil belajar kimia antara siswa yang belajar dengan strategi flipped classroom dan ekspositori pada siswa yang memiliki kemandirian belajar tinggi.

4. Terdapat perbedaan hasil belajar kimia siswa yang belajar dengan strategi pembelajaran flipped classroom dan siswa yang belajar dengan strategi pembelajaran ekspositori untuk siswa yang memiliki kemandirian belajar rendah. 
Formatif: Jurnal Ilmiah Pendidikan MIPA

Vol. 9, No. 4, December 2019, pp. 267-280

p-ISSN: 2088-351X

e-ISSN: $2502-5457$

DOI: http://dx.doi.org/10.30998/formatif.v9i4.2929

\begin{tabular}{|c|c|c|c|c|c|c|c|c|c|c|}
\hline \multicolumn{11}{|c|}{ Independent Samples Test } \\
\hline & & \multicolumn{2}{|c|}{$\begin{array}{c}\text { Levene's Test for Equality of } \\
\text { Variances }\end{array}$} & \multicolumn{7}{|c|}{ t-test for Equality of Means } \\
\hline & & \multirow[b]{2}{*}{$\mathrm{F}$} & \multirow[b]{2}{*}{ Sig. } & \multirow[b]{2}{*}{$t$} & \multirow[b]{2}{*}{ df } & \multirow[b]{2}{*}{ Sig. (2-tailed) } & \multirow{2}{*}{$\begin{array}{c}\text { Mean } \\
\text { Difference }\end{array}$} & \multirow{2}{*}{$\begin{array}{l}\text { Std. Error } \\
\text { Difference }\end{array}$} & \multicolumn{2}{|c|}{$\begin{array}{l}95 \% \text { Confidence Interval of the } \\
\text { Difference }\end{array}$} \\
\hline & & & & & & & & & Lower & Upper \\
\hline \multirow[t]{2}{*}{ LO Chemistry } & $\begin{array}{l}\text { Equal variances } \\
\text { assumed }\end{array}$ & .266 & .611 & 2,218 & 22 & .037 & 3,667 & 1,653 & .239 & 7,095 \\
\hline & $\begin{array}{l}\text { Equal variances not } \\
\text { assumed }\end{array}$ & & & 2,218 & 21,529 &, 037 & 3,667 & 1,653 &, 234 & 7,099 \\
\hline
\end{tabular}

Berdasarkan hasil independent sample test diperoleh nilai Sig (2 tailed) 0,037, dengan menggunakan nilai signifikansi $\alpha=0,05$ diperoleh nilai Sig $0,03<0,05$ sehingga $\mathrm{H}_{0}$ ditolak. Artinya pada siswa yang memiliki kemandirian rendah strategi pembelajaran ekspositori lebih sesuai, karena dengan pembelajaran flipped classroom skor hasil belajar yang diperoleh lebih rendah.

\section{Pembahasan}

Hasil belajar siswa dengan pembelajaran flipped classroom terbukti lebih tinggi dibandingkan hasil belajar siswa dengan strategi pembelajaran ekspositori. Pada pembelajaran ekspositori siswa hanya menunggu dan menerima apa yang akan diberikan oleh guru saat di dalam kelas. Siswa bersifat pasif dan hanya menerima pengetahuan yang diberikan oleh guru, proses pembelajaran bersifat teacher center (berpusat pada guru). Menurut Nance Speizman dalam artikel Questioning as thinking: a metacognitive framework to improve comprehension of expository text, pola interaksi yang didominasi oleh guru dalam proses pembelajaran akan mengarahkan siswa mempertahankan sikap pasifnya. Akibatnya siswa gagal dalam menciptakan pola pemecahan masalah dalam belajarnya. Kondisi ini berbeda dengan proses pembelajaran dua arah (siswa aktif) seperti pada proses pembelajaran flipped classroom, di mana interaksi tidak didominasi oleh guru, akan memberikan kesempatan kepada siswa untuk membangun kerangka berpikir mereka melalui diskusi, baik dengan teman sekelas maupun dengan guru. Akibatnya, siswa hanya menerima sebagian pengetahuan yang diberikan oleh guru, tanpa memiliki kemampuan untuk menambah atau mencari serta membangun pengetahuan baru untuk mendukung pengetahuan sebelumnya. Sebagai dampaknya, hanya sebagian pengetahuan yang ditransfer oleh guru yang dapat diterima siswa. Pada strategi pembelajaran ekspositori ini bisa saja apa yang disampaikan oleh guru merupakan materi yang sudah lengkap serta sistematis, namun proses transfer dan kondisi siswa sebagai penerima pesan sangat menentukan keberhasilan proses pembelajaran ini.

Dengan fakta ini pembelajaran flipped classroom ke depan bisa menjadi alternatif pembelajaran dalam rangka mencapai tujuan pembelajaran sekaligus upaya peningkatan mutu pendidikan. Bahkan strategi ini akan terus dapat dioptimalkan melalui peningkatan kualitas video pembelajaran, misal dengan video interaktif yang dapat meningkatkan motivasi belajar siswa. Diharapkan dengan video interaktif, persentase siswa yang tidak melakukan pembelajaran mandiri berkurang, bahkan tidak ada sama sekali. Di samping itu pembelajaran dapat dilakukan secara online yang terintegrasi dengan sistem penilaian. Hal ini akan lebih mengikat kepada siswa, karena saat ini siswa akan merasa bertanggung jawab jika pembelajaran dikaitkan dengan proses penilaian. Penilaian proses dapat dilakukan oleh guru melalui sistem daring. Hal ini akan meringankan beban guru tatkala harus menilai proses pembelajaran di kelas secara manual. Dengan teknologi, semua pekerjaan guru akan lebih ringan termasuk proses penilaian.

Hal yang ingin kami sampaikan dalam artikel ini adalah bahwa guru, sekolah, dinas pendidikan dapat mengambil manfaat yang banyak, bahkan tak terhingga dari era industri 4.0 ini karena dalam kondisi digitalisasi ini, saat siswa kita adalah native digital, 
Formatif: Jurnal Ilmiah Pendidikan MIPA

Vol. 9, No. 4, December 2019, pp. 267-280

p-ISSN: 2088-351X

e-ISSN: $2502-5457$

DOI: http://dx.doi.org/10.30998/formatif.v9i4.2929

pekerjaan guru akan menjadi lebih praktis sekaligus dinamis. Guru dapat meningkatkan kinerjanya dengan bantuan teknologi, guru dapat mengoptimalkan pelayanan pendidikan terhadap siswa, memfasilitasi pembelajaran dengan baik dan lebih mudah. Artinya era industri 4.0 adalah harapan sekaligus tantangan bagi guru, dosen, pemerintah, serta masyarakat. Harapan dapat dimaknai bahwa dunia pendidikan akan lebih terpacu dengan percepatan yang sangat tinggi, dalam lingkungan digital yang memiliki ciri, semua pekerjaan menjadi praktis, cepat, dan mudah. Harapannya, siswa dapat belajar dengan lebih cepat dan mendalam untuk semua kompetensi, di mana pun, kapan pun, dan bersama siapa pun. Ke depan, siswa tidak lagi hanya dapat belajar dan berkelompok dengan teman sekelas, satu sekolah, tetapi siswa akan dapat belajar bersama siswa lain di seluruh dunia. Bukankah ini suatu harapan yang sangat besar bagi dunia pendidikan? Di samping itu, kinerja guru akan meningkat dengan fasilitas yang serba canggih dengan teknologi. Guru dapat menyimpan semua data materi pelajaran yang telah dibuatnya. Terkait video pembelajaran, guru dapat membuat atau mencari link pembelajaran yang kredibel yang kemudian dapat direkomendasikan kepada siswa untuk dapat diakses. Guru dapat melakukan penilaian terhadap siswa secara paralel dengan saat proses pembelajaran berlangsung melalui penilaian online. Ke depan, guru akan dapat merunut perjalanan dan perkembangan semua siswa dengan mudah, hanya dengan mengklik big data yang kita miliki. Guru akan dengan mudah mengetahui positioning siswa dengan mudah tanpa harus mengalkulasi nilai-nilai siswa secara manual. Namun demikian, ini adalah tantangan terbesar perjalanan guru sepanjang sejarah. Di mana semua informasi akan masuk kepada semua siswa tanpa batas, dan siswa dapat mengakses apa pun, kapan pun, di mana pun dari satu alat yang bernama gadget tanpa kontrol yang terlalu berarti dari lingkungan. Karena gadget menjadi barang pribadi yang siap memberikan segala kebutuhan dari pemiliknya. Dalam kondisi ini, orang tua, guru, masyarakat, akan sulit mengontrol aktivitas siswa, apa yang sedang mereka akses dari barang pribadi yang bernama gadget tersebut. Lantas apa yang dapat dilakukan para guru? terdapat beberapa hal yang dapat dilakukan guru untuk mengurangi aktivitas negatif dari siswa, antara lain 1) Menanamkan keyakinan dan moral yang baik, tentang tugas kita sebagai manusia sesuai dengan agama masing-masing; 2) Menanamkan sikap tanggung jawab kepada siswa, bahwa segala tindakan akan mendapat penilaian, apresiasi, serta sanksi; 3) Memberikan wawasan tentang harapan dan tantangan kepada siswa tentang era industri 4.0 yang dikenal dengan desruptive innovation; 4) Membangun komunikasi dan kerja sama dengan orang tua/wali siswa, masyarakat, dinas pendidikan serta dinas terkait lainnya, dunia industri, untuk bersama menghadapi tantangan era industri 4.0 ini.

\section{PENUTUP}

Kompetensi siswa terbukti meningkat dengan pembelajaran yang mengintegrasikan teknologi ke dalam prosesnya. Era Industri 4.0 yang ditandai dengan digitalisasi menjadi peluang bagi dunia pendidikan untuk melesat dengan percepatan yang tinggi dalam meningkatkan mutu dan kualitasnya. Salah satu strategi pembelajaran yang terbukti efektif dalam meningkatkan hasil belajar siswa adalah strategi flipped classroom. Flipped classroom dengan segala bentuk dan modifikasinya akan dapat mengikuti era industri 4.0. Flipped classroom akan memberikan keleluasaan kepada generasi milenial untuk mengeksplorasi semua kemampuannya, secara lebih mandiri namun bertanggung jawab. Flipped classroom ke depan akan menggunakan video pembelajaran interaktif, virtual lab, link dengan teknologi tinggi yang dapat membantu guru dalam memfasilitasi semua kebutuhan siswa secara cepat dan layak. Flipped 
Formatif: Jurnal Ilmiah Pendidikan MIPA

Vol. 9, No. 4, December 2019, pp. 267-280

p-ISSN: 2088-351X

e-ISSN: 2502-5457

DOI: http://dx.doi.org/10.30998/formatif.v9i4.2929

classroom juga terbukti mencetak generasi mandiri dan bertanggung jawab sesuai dengan kebutuhan era industri 4.0. Siswa dilatih belajar secara mandiri serta dilatih untuk bertanggung jawab terhadap apa yang dilakukannya selama proses pembelajaran.

Berikut ini adalah sebagian video pembelajaran yang telah di-upload ke YouTube untuk menunjang proses pembelajaran flipped Classroom:

1. Daftar Link ke Channel YouTube: https://www.youtube.com/channel/UCUUANdujZjqLeE-0P_t3fLw

2. Reaksi Eksoterm \& Endoterm: https://www.youtube.com/watch?v=mskJZHOrn5o

3. Penentuan Delta $\mathrm{H}$ reaksi : https://www.youtube.com/watch?v=42tUm_Az2YQ

4. Algoritmik Hukum Hess : https://www.youtube.com/watch?v=9yn5mDDOtnk

5. Cara menghitung Delta $\mathrm{H}$ reaksi dengan Energi ikatan : https://www.youtube.com/watch?v=R0BtPS9GpfI

\section{DAFTAR PUSTAKA}

Abubaker Kashada. (2017). Adoption of flipped classroom in k-12 education in developing countries: Challeges and obstacles. iJET, 12 (10).

Adam M. Persky, Jacqueline E. McLaughlin. (2017). The flipped classroom-from theory to practice in health professional education. American Journal of Pharmaceutical Education, 81 (6).

Ahmet Basal. (2015). Implementation of a flipped classroom in foreign language teaching. Turkish Online Journal of Distance Education, 16.

Bergmann J, Rotellar C, Cain J. (2016). Research, perspective, and recommendation on implementing the flipped classroom. American Journal of Pharmaceutical Education.

C. Lo, Kew. (2017). A critical review of flipped classroom challenges in k-12 education: Possible solutions and recommendation for future research. Research and Practice in Technology Enhanced Learning, 12 (1).

Cherie L Yestrebsky. (2014). Flipping the classroomin a large chemistry class_ research university environment. Proceedings of Chemistry Departement, University of Central Florida, 2014.

Cockrum Troy. (2014). Flipping Your English Class. New York: Routledge.

Donald Ary, Lucy Cheser Jacobs, dan Chris Sorensen. (2010). Introduction to Research in Education. Eight Edition, USA: Cengage Learning.

Eric M Carbaugh, Kristina J. Doubet. (2014). The Differentiated Flipped Classroom. California: Corwin.

Hmelo-silver, Cindy E., Clark A. Chinn, Carol K. K. Chan, and Angelo O'Donnel. (2013). The International Handbook of Collaborative Learning. New York: Routledge.

Hoda Baytiyeh. (2016). The flipped classroom model: when technology enhances professional skills. Journal of The International Journal of Internasional and Leraning Technology, 34 (1), 51-62.

Loyens, S,M. (2014). New approaches problem based learning: Revitalizing your practice in higher education. The Interdisciplinary Journal of Problem-based Learning, 8 (2). 
Formatif: Jurnal Ilmiah Pendidikan MIPA

Vol. 9, No. 4, December 2019, pp. 267-280

p-ISSN: 2088-351X

e-ISSN: 2502-5457

DOI: http://dx.doi.org/10.30998/formatif.v9i4.2929

Nance Speizman Wilson and Linda Smetana. (2011). Questioning as thinking: A metacognitive framework to improve comprehension of expository text. (Published by Blackwell, 2011) Vol. 45 Number 2 July 2011.

O.N Agbulu, E.E Idu. (2008). The impact of participatory and expository approaches on learning of agricultural science in senior secondary schools in Benue State. J.Soc.Sci, 16 (3),245-249.

Oscar Flores, Isabel Del-Arco, Patricia Silva. (2016). The flipped classroom model at the university: Analysis based on professors' and student assessment in the educational field. International Journal of Educational Technology in Higher Education, 13 (21).

Sharon E. Smaldino, Deborah L. Lowther, Clif Mirns, James D. Rusell. (2016). Instructional Technology and Media for Learning. New York: Pearson.

Troy Cockrum. (2014). Flipping Your English Class to Reach All Learners. New York: Routledge.

Yi li. (2018). Current problems with the prerequisites for flipped classroom teaching: A case study in a university in Northwest China. Li Smart Learning Environment, 5 (2).

Admin. (Januari, 2018). Era Evolusi Industri 4.0 Saatnya Generasi Millennial Menjadi Dosen Masa Depan. Ristekdikti.go.id. diakses pada 10 September 2018 di http://sumberdaya.ristekdikti.go.id/index.php/2018/01/30/era-revolusi-industri-4-0saatnya-generasi-millennial-menjadi-dosen-masa-depan

Admin. (--). Mendikbud Ingatkan Tantangan Era Revolusi 4.0. Krjogja.com. diakses pada 10 September 2018 di http://krjogja.com/web/news/read/65813/Mendikbud_Ingatkan_Tantangan_Era_Re volusi_Industri_4_0 